\title{
Carnets
}

Revue électronique d'études françaises de l'APEF

Première Série - 2 Numéro Spécial | 2010

Littératures nationales: suite ou fin. Résistances, mutations \& lignes de fuite

\section{Editorial : Littératures nationales: quelle suite, quelle fin?}

José Domingues de Almeida, Maria de Jesus Cabral et Lénia Marques

\section{(2) OpenEdition}

Journals

Édition électronique

URL : http://journals.openedition.org/carnets/4780

DOI : $10.4000 /$ carnets. 4780

ISSN : 1646-7698

Éditeur

APEF

Édition imprimée

Date de publication : 1 juin 2010

Pagination : 5-5

Référence électronique

José Domingues de Almeida, Maria de Jesus Cabral et Lénia Marques, « Editorial : Littératures

nationales: quelle suite, quelle fin? », Carnets [En ligne], Première Série - 2 Numéro Spécial | 2010, mis en ligne le 16 juin 2018, consulté le 24 septembre 2020. URL : http://journals.openedition.org/carnets/ 4780 ; DOI : https://doi.org/10.4000/carnets.4780

Carnets est mis à disposition selon les termes de la licence Creative Commons - Atribution - Pas d'utilisation commerciale 4.0 International. 


\section{EDITORIAL}

\section{Littératures nationales: quelle suite, quelle fin?}

Nos littératures nationales sont-elles encore "nationales"? Ou sont-elles en train de changer à la faveur de phénomènes dont la portée et la signification vont du local au global? Le contexte historial dans lequel elles ont émergé et se sont institutionnalisées demeure-t-il encore valable alors que d'autres soucis et d'autres thématiques sont venus s'immiscer dans le fait littéraire jusqu'à, selon d'aucuns, en décaractériser la nature ou la raison d'être?

Et pourtant, malgré les mutations à caractère infra- ou supranational, les attaches institutionnelles et affectives à la réalité nationale s'avèrent puissantes, voire surprenantes.

C'est à l'approche critique et à l'illustration de toutes ces questions d'actualité que les textes rassemblés dans ce numéro spécial s'attèlent. Ils ont, qui plus est, le mérite de provenir de, ou de se référer à différents contextes nationaux et littéraires dont ils problématisent les enchevêtrements spécifiques, qu'ils soient historiques, mondialisés, mythiques, folkloriques, régionalistes, écologiques, identitaires ou interculturels.

Nous remercions leurs auteurs d'avoir contribué à engager ce débat qui s'annonce imprévisible et dont les enjeux restent toujours à approfondir.

Nous invitons, pour l'heure, les chercheurs à lire et commenter ces apports critiques, à mener plus loin la réflexion sur l'avenir des littératures nationales et à s'aventurer dans d'autres corpora littéraires en vue d'autres rendez-vous. Bonne lecture!

JosÉ DOMINGUES DE ALMEIDA

MARIA DE JESUS CABRAL

LÉNIA MARQUES

(Editeurs) 